\title{
Proposed Conceptual Model Internationalization of Small Medium Industries (SMIs) in Indonesia: The Relationship between Entreprenurial Orientation, Network Capital, Degree of Internationalization and Business Performance
}

\author{
Ginta Ginting ${ }^{1}$ \\ ${ }^{1}$ Faculty of Economic - Study Program of Management, Universitas Terbuka, Indonesia \\ Correspondence: Ginta Ginting, Faculty of Economic - Study Program of Management, Universitas Terbuka - \\ Indonesia. E-mail: ginta@ut.ac.id; gintaginting3@gmail.com
}

Received: July 30, 2013 Accepted: August 15, 2014 Online Published: September 29, 2014

doi:10.5539/ass.v10n19p220 URL: http://dx.doi.org/10.5539/ass.v10n19p220

\begin{abstract}
The proposed model of SMIs in conducting internationalization business is to investigate the entrepreneurial orientation and network capital in influencing international business and its impact on business performance in SMIs. This model also uses the size of SMIs as moderator variables that influence the degree of internationalization and business performance. This model can be implemented for research areas of internationalization of small medium enterprises especially for developing country like Indonesia.
\end{abstract}

Keywords: entrepreneurial orientation, network capital, degree of internationalization, business performance and SMIs.

\section{Introduction}

Small and medium industries (SMIs) are important sectors in improving world economy and contribute significantly to the national economy of a country. Based on European Comission report, definition of SMIs adopted by each country is different, in Canada SMIs defined as enterprises engaged in the manufacture or production, processing or preservation of goods with fewer than 100 employees (if the business is a goods-producing one) or fewer than 50 employees (if the business is service-based), and a medium-sized business as one with fewer than 500 employees. In Australia, an SMI has 200 or fewer employees (Small Business 3-15 employees and Medium 16-200 employees). In Israel, a business is considered small if it has not more than 50 employees. A medium business holds between 51 to 250 workers. (European Comission, 2003). SMIs is the backbone of the global economy, more than 95\% of SMIs are members of the OECD (The Organization of Economic and Cooperation) and gives major contribution to job creation, innovation and economic growth (Dalberg, 2011, p. 7). The same opinion is expressed by Bhasin and Venkataramany (2010, p. 95), that "SMIs are overwhelming importance to the young and growing economies of most Southeast Asian Nations, Including Indonesia". The number of SMIs in Indonesia reaches 3,982,429 units, or 16.1\% of the total small medium enterprises (SMEs) (Ministry of Industry-Strategic Plan: 2010-2014", 2011, p. 18). SMIs in Indonesia play an important role in encouraging the growth of the national economy. This condition can be seen from the structure of the industry in Indonesia, where small entrepreneurs together with Privately Owned Enterprises (POEs) and the State-Owned Enterprises (SOEs) become three important economic actors that support the development of the industrial sector in Indonesia. SMI has a very important role in supporting Indonesia's economic resilience in employment at the grass root level. Labor can be absorbed in SMIs up to 2011 is large enough that of $8,268,588$ people (small industries) and 247,610 people (medium industries), compared to large industries that can absorb approximately 6,156,057 people. However, the value of its contribution to the economy still needs to be improved, the amount of donation by SMIs in 2011 is 33\% (\$44,082.9 Million) compared with the contribution of major industries in the amount of $\$ 87,617.7$ (Ministry of Industry-Strategic Plan: 2010-2014", 2011, p. 18).

The low value contribution of SMIs is partly due to the various constraints faced. In general, the constraints faced by SMIs due to several factors: 1) weakness in accessing and developing market. 2) weakness in the capital structure and limited access to capital resources. 3) limitations in building a network (global) and 
cooperation. 4) limitations in accessing to and controlling technology. 5) lack of business information. 6). Difficulties in obtaining raw materials. 7) the high level of competition due to economic globalization and trade liberalization (Bhasin \& Venkataramany, 2010, p. 98). General Director of SMIs-Ministry of Industry states that the real obstacle still faced by SMIs in Indonesia are: 1) the entrepreneurial spirit is still very low; 2) SMIs products are not competitive due to the lack of continuous quality and standards; 3 ) not well able to forge partnerships with major industry; 4) lack of market information; 5) low accessibility to sources of capital (Ministry of Industry a directorate of SMI, 2009).

Along with the trend of market globalization and trade liberalization, within the last decade, companies included in small and medium-sized enterprises have conducted a variety of international activities (Daft, 2010). The number of SMIs who conduct international activities shows an increase. The condition is driven by market opportunities and the development of communication technology, information and transportation. As stated by McDougall and Oviatt (2003, p. 3) that "recent technological advances and cultural awareness that appear to open untapped foreign markets to new ventures". Then, Wengel and Rodriguez (2006, p. 26) states that "with a depressed local market and a higher local price of their products, SMIs had to find new markets and many switched to the international market". On the other hand, the research results of Patich and Bagby (2006 on Wismiarsi et al., 2008) suggests that the small-scale business is experiencing growth leads to the internationalization of the market.

In the Indonesian context, export activity is a traditional way which is generally used by various business units, including medium-to small-scale work on the international market (Wismiarsi et al, 2008, p. 8). SMIs that do international business (export-oriented) reach 11 billion U.S. dollars with an average growth rate of 5-6\% per year (Ministry of Trade-Dit.Jen.NED, 2012). Internationalization has provided opportunities for SMIs in developing their business. Verdin and Heck (2001, p. 59) states there are three main benefits for companies that undertake internationalization: cost advantage, network benefits and learning opportunities. Studies conducted on 400 SMIs in Malaysia have identified the reason why doing international business, namely: 1) to increase profit $(36.7 \%), 2)$ the existence of market opportunities $(23.9 \%), 3)$ business expansion and marketing the product (12.8\%), and 4) as entrepreneurial motivation (13.8\%) (Abdulah \& Zain, 2011, p. 320). The two studies are essentially able to show that the decision of SMIs to conduct international business, among others, fueled by the desire to improve the performance and expand the market. Doing international business, among others, through the export not only provide "earnings return" because the value of the foreign currency is more valuable, the actors of SMIs can open new markets that will have an impact on a larger return (Wengel \& Rodriguez, 2006).

But for SMIs, doing international business gives tough challenges. Challenges faced are not easy because they have to prepare themselves to face the strong competition with the business actors in the international market. With regard to the internationalization of SMIs, OECD Centre for Entrepreneurship and SME in the report entitled Top Barriers and Drivers to SME Internationalization (2009, p. 6), explains several main problems faced by SMIs in Indonesia in conducting international business: 1) lack of working capital to finance exports. 2) identification of business opportunities abroad. 3) lack of information to analyze market. 4) inability to contact potential overseas customers. 5) difficulty in getting overseas representatives who can be trusted. 6) the unavailability of trained personnel for internationalization. 7) the difficulty in adjusting prices with competitors. 8) lack of government support (incentives) (OECD, 2009, p. 8). SMI involvement in the conduct of international business is still facing many obstacles. Tambunan $(2007 \mathrm{~b}$, p. 75$)$ states that there are two important issues currently faced by SMIs namely: 1) whether they can become an important player in the global markets and not only serve the domestic/local market only. 2) whether they are able to compete with large industry. The amount of non-oil exports reached by SMIs ranged from 17 to $18.9 \%$ in 2009-2011 (Minister of Industry, "Strategic Plan: 2010-2014", 2011, p. 57). This figure shows that the achievement is not optimal from the government target of $40 \%$ per year.

Furthermore, reports of APEC in 2008 (at Bhasin and Venkataramany, 2010, p. 99) regarding the lack of SMIs exports shows that at the time of globalization, SMIs work fast, but only a small amount $(0.05 \%)$ of Indonesian exporters who export directly, most of the exports are done through a third party. According to Tambunan (2010a, p. 15) there are four ways in which the SMIs in Indonesia to export, namely: 1) export directly without going through an intermediary, 2) export indirectly through intermediaries (subcontracting by large companies, traders, agents). 3) export indirectly by selling products to tourists from abroad who come to Indonesia, 4) export indirectly by producing components or semi-finished goods purchased by foreign tourists visiting to Indonesia or to meet the demands of domestic large enterprises. This condition causes the unrecorded data of SMI export actors which is indicated by the low SMIs export contribution. 
The export activities of SMIs actors through a third party (intermediary) is a "buyer-driven commodity changes", where the intermediary agencies play a big role in making the design, pricing, technology and production time (Tambunan, 2010b, p. 16). Dependence on third parties are caused by several obstacles, such as lack of financial access to foreign markets, many products do not meet export standards and inability to understand the information related to the world market. Then, report of "Global Small Business Confidence Monitor" conducted by HSBC Commercial Banking (2010, p. 18), shows the main constraints of SMIs in Indonesia in conducting international business (export) directly are in the licensing terms of exports, high taxes, and the fulfillment of various certifications such as Sucofindo and ETPIK.

One of the dominant aspects of the cause of the low degree of internationalization is low entrepreneurial orientation. Sources from the Ministry of Industry estimate that Indonesia only has 440,000 entrepreneurs or $0.18 \%$ of the total population, while in developed countries like the USA and Singapore, the number of entrepreneurs reach $11.5 \%$ and $7.2 \%$ of the total population (Gema, Dec., 2010, p. 11). Entrepreneurship ratio compared to the population of Indonesia is only 1:83, while in the Philippines 1:66, Japan 1:25, and Korea is less than 20. Internationally, the ideal ratio is of 1:20 (Suryana \& Bayu, 2010, p. 1). Some of the data and the results of these studies indicate that the entrepreneurial orientation of the entrepreneurs are less willing to take risks, less innovative, and less able to compete aggressively, all of which are thought to still be real problems of SMIs in Indonesia.

In addition to the application of entrepreneurial orientation issues, the not optimal of SMIs in doing business internationally is also due to the low ability to build networks. SMIs limitations to build networks lead to difficulties in terms of: access to knowledge, resources and entry into international markets (Cerrato and Piva, 2008, p. 5). Network is an important factor so that SMIs can survive and is able to compete with businesses in overseas markets (Farinda et al, 2009, p. 151). Network plays an important role in the internationalization as stated by Zain and $\mathrm{Ng}$ (2006, p. 183) "SMEs use their networks to facilitate their internationalization process". The same opinion is expressed by Chen et al $(2011$, p. 705) that "it has been recognized that long-term relationship with SMIs form a strategic network partners offer the benefits. Because they provide direct and indirect access to key resources, skills and knowledge controlled by other members within the network". This opinion basically states that long-term relationships built by SMIs with a network partner offers strategic benefits because they can provide direct and indirect access to essential resources, knowledge and skills which are under the supervision of a partner network. Network play a strategic role for the development of SMIs as stated Awuah and Charity (2011, p. 129) "to increase of their competitiveness to face with globalization, SMIs have to establish a network with other organizations, where they complement each other through sharing of resources and activity and joint learning to international boost intensity".

The purpose of this study is to contribute to the development of knowledge by proposing a model of the relationship of entrepreneurial orientation, network capital, degree of internationalization, and companies performance. Models and constructs are developed from the literature. The findings of the study have important implications for owners of SMIs to go international as well as to provide input for the government to facilitate awareness and encourage SMIs to take advantage of the international market.

\section{Entrepreneurship and Network as Basis of Internationalization}

Entrepreneurship is the ability to create something new and different (Drucker, 1994). So, according to its epistemology, entrepreneurship is "the value required to start a business in doing something new and something different by applying creativity, innovation and courage to face the risk done by hard working to establish and maintain new business" (Winarno, 2011, p. 11). In addition, some other experts argue that the essence of entrepreneurship reflects the "firm-level behavior" and "entrepreneurial process", namely innovativeness, proactiveness, and risk taking in the context of: 1) high-tech small firms (Quience and Whittaler, 2003, p. 20). 2) Growth of SMIs (Moreno and Casillas, 2008, p. 521). 3) improved business performance (Fairoz et al, 2010, p. 39). 4) looking for new opportunities (Lan \& Wu, 2010, p. 67). 5) changing old business practices into the new business practices (Chen et al, 2011, p. 704). Essence of those opinions is the organization that has entrepreneurial behaves (innovativeness, risk taking, proactiveness and competitiveness) can have an impact on performance improvement.

Entrepreneurial orientation theory was first developed by Miller in 1983, followed by Covin and Slevin (Covin and Slevin, 1989) and Lumpkin and Dess (1996). According to Lumpkin and Dess (1996, p. 137), "Entrepreneurial orientation as the processes, practices and decision-making activity that leads to new entry". It refers to the specific organizational-level behaviors to perform risk-taking, self-directed activities, engaged in innovation and react positively and aggressively to outperform the competitors in the marketplace". This can be 
defined as the process of entrepreneurial orientation, practices, and decision-making activities that lead to new entry. Entrepreneurial orientation refers to the level of specific behavior of company in facing risk, independent activities, engaging in innovation and reacting positively and aggressively to outperform the competitors in market.

Wiklund and Shepherd (2005, p. 74) suggest the definition of entrepreneurial orientation as the company's strategic orientation that is "the firm's strategic orientation, capturing specific entrepreneurial aspects of decision making styles, methods, and practices". The same opinion is expressed by Frank et al (2010, p. 177) that "Entrepreneurial orientation is a firm's strategic orientation, one roomates captures the specific entrepreneurial aspect of decision making, styles, methods and practices. Entrepreneurial orientation represents a continuum ranging from more or less conservative to entrepreneurial firms, that is, it expresses a fundamental strategic posture. ". From both opinions, it can be concluded that entrepreneurial orientation is a strategic orientation that implements aspects of decision-making, styles, methods and practices that demonstrate the level of conservative companies to implement corporate entrepreneurship. During its development, entrepreneurial orientation is defined more broadly, as stated by Rauch $(2009$, p. 763) that entrepreneurial orientation "represent the policies and practices that provide a basis for entrepreneurial decision and actions". Thus, entrepreneurial orientation can be viewed as the entrepreneurial strategy making process that the key decision makers use to enact their firm's organizational purpose, sustain it vision, and create competitive advantages.

From some of the above understandings, it can be concluded that an entrepreneurial orientation is: the level of organizational behavior related to actions that are entrepreneurial (risk-taking, innovativeness, proactiveness, competitive aggressiveness and autonomy) that describes specific aspects relating to decision-making, methods, practices and styles applied in a company in its efforts to become a company that applies the principles of entrepreneurship.

Network capital is a concept that evolves with the concept of inter-firm network (Gulati, 1999, p. 1439) of "company enters a new form of strategic alliance which is a strategic alliance between organizations: dependence and a close relation". Some experts (Wellman \& Frank, 2000, p. 1; Acevedo, 2007, p. 1) define network capital and relate it with social capital. Wellman and Frank (2000, p. 1) describe "network capital as the form of social capital that makes resources available through interpersonal ties. It is available, Instant, usually specialized, and unevenly distributed among people, ties and networks. Thus network capital operates through many aspects of interpersonal life that the make resources available". Similar opinion is expressed by Acevedo (2007, p. 1) who states that "network capital is a specific type of social capital in the network society and it holds significant value for the advancement of human development around the world". So, in essence both definitions emphasize that network capital is a form of social capital in an effort to increase the availability of resources through interpersonal relations in society for the public interest.

The concept of social capital is a concept that, among others, proposed by Nahapiet and Ghoshal (on Tsai \& Ghoshal, 1998, p. 464) who states that "social capital defined as the actual and potential resources embedded within, available through and derived from the network relationship possessed by an individual or organization ". It means that social capital is the actual and potential resources that can be mutually owned by an individual or organization through a network relationship". Dimensions of social capital Nahapiet and Ghoshal (on Tsai \& Ghoshal, 1998, p. 465), consist of: 1) structural dimension (relations between individuals in the community through: friendship, family, government officials, connections with community leaders). 2) relational dimensions (personal relationship based on friendship and trust). 3) cognitive dimensions (referring to aspects of communication using a language that carries similarity in meaning). In the context of SMIs, Cooke and Wills (1999, p. 219) state that "Social capital is a communal property involving civic engagement, associational membership, high trust and reliability in the social networks". This definition implies wealth/property jointly owned involving the community bond, members of the association, high confidence, reliability and interaction in a social network.

Another definition proposed by Morales and Fernandez (2010, p. 261) that "Social capital is defined as the norms and social relations embedded in the social structures of society that enable people to coordinate action and to achieve desired goals". This definition states that social capital is the norms and social relations that exist in the social structure of the community so that community members can coordinate with each other and achieve the expected goals". Dimensions contained in the definition of social capital Morales and Fernandez (2010, p. 258) are: trust, social relationships, and shared visions. These definitions imply that social capital suggests that individuals/organizations in the community can have a resource to each other based on the principle of norms, social relationships, trust, interaction, and through the creation of a network relationship. 
Furthermore, Huggins (2010, p. 520) explains the concept of social capital and network capital as a kind of network resources. Network resources are an overarching concept to be able to explain and understand the resources and the capital generated through inter-firm networks (Gulati, 2007; at Huggins 2009, p. 335). Huggins (2009, p. 335) defines network capital as "consisting of investments in calculative relations by firms through which they gain access to knowledge to enhance expected economic returns. Huggins (2010, p. 522) distinguishes social capital with a network capital by stating that "social capital consisting of the social relations and networks held by individuals" which means capital includes social and network relationships done individually, while "network capital consisting of the strategic and calculative relations and networks held by firms" meaning capital network includes strategy and calculative relationships and networks are run by different companies. Then, Huggins (2010, p. 348) emphasizes that the concept of "network capital is a means of capturing the resources contained within inter-firm network based on business logic of professional expectations. Social capital is more likely to be built by social networks. It can be concluded that the capital can be used to access network resources owned between companies based on logical principles, professional, strategic and calculative. While social capital is based more on social networks.

Important essence of literature review regarding entrepreneurial orientation and network capital in the context of the internationalization is that SMIs with different obstacles are able to reach international market opportunity if supported by a strong entrepreneurial orientation, namely brave to face the risk, innovative, proactive and able to compete aggressively. Entrepreneurship is not enough and it needs to be supported by network with partners to get access to resources and knowledge as well as market opportunities.

\section{Model Conceptual and Research Hypotheses}

Model conceptual proposed in this study on the relationship among entrepreneurial orientation, network capital, the degree of internationalization and performance are as follows:

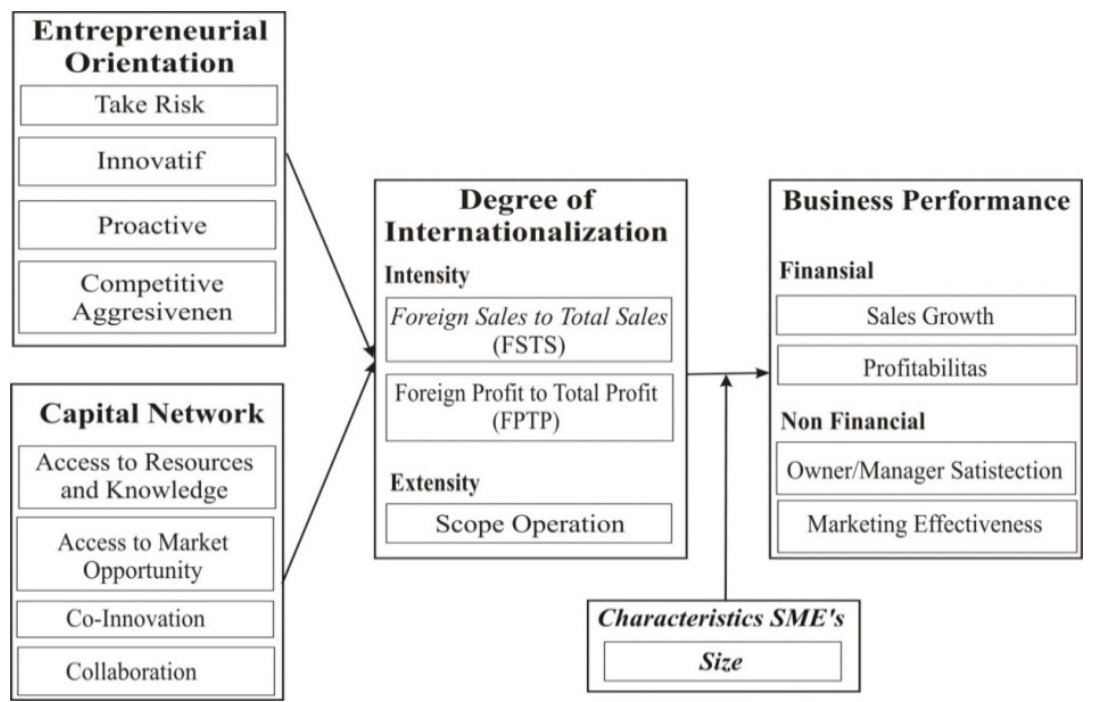

Figure 1. Conceptual model

In the proposed model, the entrepreneurial orientation and network capital are independent construct, the degree of internationalization and performance as the dependent constructs. SMI characteristic (size) is as moderator. Entrepreneurial orientation defined is a strategic orientation adopted by entrepreneurs who exhibit characteristics, namely willingness to face risk, innovative, proactive and compete aggressively (Lumpkin \& Dess, 1996, Wiklund \& Shepherd, 2005; Rauch et al., 2009). Network capital is defined as networking capabilities to build a professional network through the use of relationships and collaborating with partners (Blomqvist \& Levy, 2006; Carson et al., 2004, O'Toole \& McGrath, 2008). The construct degree of internationalization is defined as degree/intensity of SMI in the conduct of international business (Sullivan, 1994b; 1994a; Kuivalainen et al, 2010; Gillies, 2005). Business performance is defined as performance resulting from a strategic activity carried out by SMIs in particular in the conduct of international business (financial and non-financial). Characteristics of SMIs are defined as companies that have a workforce of 10-20 people and for the small industry and medium industries 21-99 people (Ministry of Industry- Directorate of SMI, 2009). 
Relationship between entrepreneurial orientation and the degree of internationalization is supported by the empirical study of Clerg, Sapienza and Crijns (2005); Melia, Boulard and Peinado (2007) and Lan and Wu (2010), who also support the influence of entrepreneurship orientation on the degree of internationalization. This is confirmed by Okpara (2009b) who argues that "entrepreneurial orientation in relation to utilize the opportunities of market abroad which means it must be active, proactive and aggressive in conducting international activities (export)". Empirical study results can be used as the basis of determining the hypothesis: Entrepreneurial orientation affects the degree of internationalization $(\mathrm{HI})$.

Network capital relationship and the degree of internationalization on several empirical studies do not directly tested on, but several studies using dimensions related to network capital such as Camison and Villar (2008) to build a strong position in the market with partners to partner to gain knowledge: market, customers, reputation effect on sales of the results of international activities. Zimmerman et al (2010) investigates the role of network on international diversification (exporting, licensing foreign subsidiary sales unit). Studies Tang (2011) identifies a relationship between strong commitment to the network, open access to a variety of networks and strategies for network and the availability of network resources to the achievement of internationalization speed. Empirical study results can be the basis of determining the hypothesis: Network capital affects the degree of internationalization $(\mathrm{H} 2)$

Conceptual model proposed that the degree internationalization affects the business performance of SMIs, based on empirical studies but still obtained different results. Empirical studies (Sullivan, 1994a; Rieck et al 2005; Loncan \& Nique, 2010; Cheliah et al., 2010a) can prove the positive influence between the degree of internationalization and business performance. However, Camison and Lopez (2010) find that there is no relationship between the degree of internationalization on performance. So, the hypothesis made is: Degree of Internationalization influence on business performance (H3).

Relationships entrepreneurial orientation and network capital through the degree of internationalization on business performance of SMIs not directly tested, but some studies do partial test. Several empirical studies (Wiklund \& Shepherd, 2005; Lee \& Lim, 2009; Fairoz et al., 2010; Frank, Kessler \& Fink, 2010) prove the influence of entrepreneurial orientation and business performance. Meanwhile, the relationship of network capital with business performance shows sufficient evidence that there is a connection between the two constructs, as shown by studies conducted by several experts (Human \& Naude, 2009; Kenny \& Fahy, 2011; Ural, 2008). So the hypothesis is: Entrepreneurial orientation and network capital through the degree of internationalization affects the business performance (H4)

Characteristics of SMIs which moderate the relationship of degree of internationalization and business performance in several empirical studies do not directly tested, but several studies use relevant dimensions used in the empirical study by Chelliah et al (2010) and Babakus, Yavas and haahti (2006) which have managed to prove that firm size as a moderator variable has significant influence in strengthening the relationship between strategy (foreign networking, entrepreneurial orientation), the degree of internationalization with the performance. So, the hypothesis made is: Characteristics of SMIs (size) moderate the effects of variable the degree of internationalization on business performance (H5).

Regarding with the hypothesis development, the proposed structural model of research hypothesis can be seen in the figure 2 .

\section{Discussion and Recommendation}

The proposed conceptual model internationalization of SMIs provide a comprehensive hypothesis framework which require further empirical studies based on real facts dealing with export oriented of SMIs. This model highlighted two important independent variables entrepreneurial orientation and network capital and degree of internationalization as mediator of dependent variable (performance). For further research is that to take any consideration in selecting the units of analysis (SMIs), because they have not been able to touch directly the activities of network capital and the degree of internationalization. To develop future research, it is necessary to distinguish between the characteristics of small and medium-sized enterprises. This is important because the characteristics of each group of firms vary widely in terms of size, stage of internationalization and the ability to manage the business.

For scientific development, primarily related to the internationalization of SMIs, then further research could be done by adding the variables in this research model that greatly affect the performance of the company, naming international knowledge and experience. These two variables are important factors for SMI entrepreneurs to be able to realize the international business. So, it is proposed to conduct research on the effect of network capital 
on the degree of internationalization and business performance with moderations of international knowledge and experience.

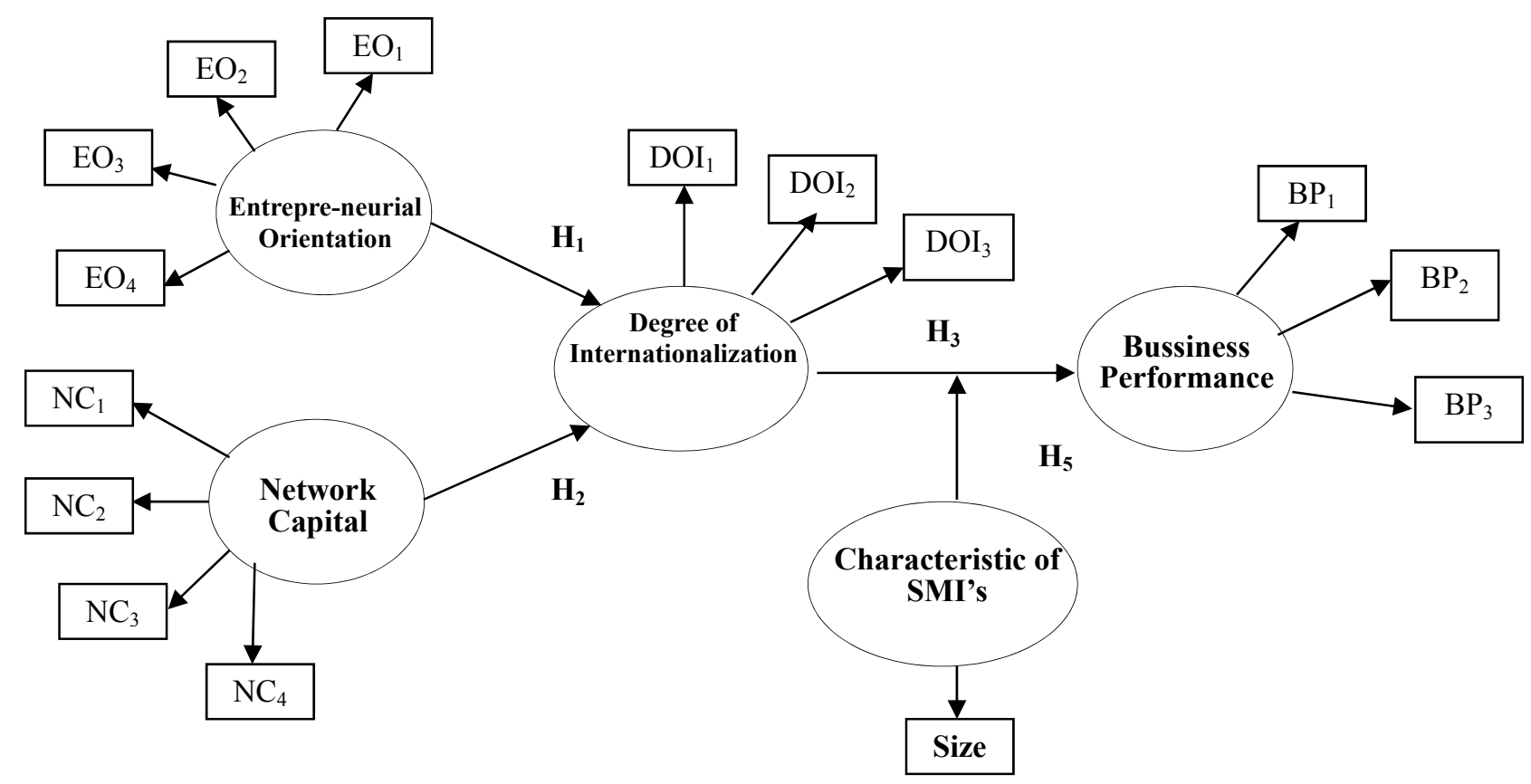

Figure 2. Proposed structural model

\section{References}

Abdulah, Nik. A. H., \& Zain, S. N. M. (2011). The Internationalization Theory and Malaysian Small Medium Enterprises (SMEs). International Journal of Trade, Economics and Finance, 2(4), 318-322.

Acevedo, M. (2007). Network Capital: An Expression of Social Capital in the Network Society. Journal of Community Informatics, 1-13.

Awuah, G. B., \& Amal, M. (2011). Impact of Globalization, The ability of Less Developed Countries (LDCs) Firms to Cope with Opportunities and Challenges. European Business Review, 23(1), 120-132.

Babakus, E., Yavas, U., \& Haahti, A. (2006). Perceived Uncertainty, Networking and Export Performance: A study of Nordic SMEs. European Business Review, 18(1), 4-13.

Bhasin, B., \& Venkataramany, S. (2010). Globalization of Entrepreneurship: Policy Consideration for SME Development in Indonesia. The International Business and Economics Research Journal, 9(4), 95-103.

Blomqvist, K., \& Levy, J. (2006). Capability: A focal concept in knowledge creation and collaborative innovation in networks. International Journal Management Concepts and Philosophy, 2(1), 31-48.

Camison, C., \& Lopez, V. (2010). Effect of SMEs International Experience on Foreign Intensity and Economic Performance: The Mediating Role of Internationally Explotable Assets and Competitive Strategy. Journal of Small Business Management, 48(2), 116-151.

Camison, C., \& Villar, A. (2008). Capabilities and Propensity for Cooperative Internationalization. International Marketing Review, 25(2), 124-150.

Carson, D., Golmore, A., \& Rocks, S. (2004). SME Marketing Networking: A strategic approach. Journal of Strategic Change, 13, 369-382.

Cerrato, D., \& Piva, M. (2008). The Internationalization of Small and Medium-Sized Enterprises: The Effect of Family Management, Human Capital and Foreign Ownership. Joint Research Project Report, 1-25.

Clerq, D. D. E., Sapienza, H. J., \& Crijns, H. (2005). The Internationalization of Small and Medium-Sized Firms. Small Business Economics, 24, 409-419. 
Chelliah, S., Pandian, S., Sulaiman, M., \& Munusamy, J. (2010). The Moderating Effect of Firm Size: Internationalization of Small Medium Enterprise (SMEs) in the Manufacturing Sector. African Journal of Business Management, 4(14), 3906-3109.

Chen, K., Hsiung. J. M., Yien, Huang. K. P., \& Huang, C. J. (2011). Performance and Its Link to Entrepreneurial Behavior. American Journal of American Sciences, 8(7), 703-707.

Cooke, P., \& Wills, D. (1999). Small firms, social capital and the enhancement of business performance through innovation programmes. Small Business Economics, 13(3), 219.

Covin J. G., \& Slevin, D. P. (1989). Strategic Management of Small Firms in Hostile and Benign Environments. Strategic Management Journal, 10, 75-87.

Daft, R. L. (2010). Era baru Manajemen (New Era of Management). Penerbit Salemba Empat, Jakarta, edisi 9.

Dalberg. (2011). Report on Support to SMEs in the Global Economy. Retrieved April 5, 2012, from http://www.eib.org.diunduh

Eropean Comission. (2003). Recommendation SME/SMI Definition. Retrieved from http://Wikipedia.org/SME

Fairoz, F., Hirobumi, M. T., \& Tanaka, Y. (2010). Entrepreneurial Orientation and Business Performance of SME of Hambantota District Sri Lanka. Asian Social Science, 6(3).

Farinda, A. G., Kamarulzaman, Y., Abdullah, A., \& Ahmad, S. Z. (2009). Building Business Networking: A Proposed Framework for Malaysian SMEs. International Business Research Papers, 5(2), 151-160.

Frank, H., Kessler A., \& Fink, M. (2010, April). Entrepreneurial Orientation and Business Performance - A Replication Study (pp. 175-198).

Gema Industri Kecil. (2010). Kemantapan Pangan Dapat Meningkatkan Daya Saing. Jakarta: Edisi XXXI-Desember- Departemen Perindustrian-Dirjen IKM.

Gillies, G. L. (2005). Concept Issues Behind the Assessment of the Degree of Internationalization. Journal of Management Centre, 1-22.

Gulati, R. (1999). Where Do Interorganizational Networks Come From? AJS, 103(5), 1439-1493.

HSBC. (2010). Report Global Small Businesd Confidence Monitor. Retrieved April 4, 2012, from http://www.HSBC.co.id

Huggins, R. (2009). Forms of Network Resource: Knowledge Access and the Role of Inter-firm Networks. International Journal of Management Reviews, 12(3), 335-352.

Huggins, R. (2010). Network Resources and Knowledge Alliances: Sociological Perspectives on Inter Firm Network as Innovation Facilitators. International Journal of Sociology and Social Policy, 30(1), 515-531.

Human, G., \& Naude, P. (2009). Exploring the Relationship Between Network Competent and Capability and Firm Performance: A Resource-Based Perspective in an Emerging Economy. Management Dynamics, $18(1), 1-14$.

Kenny, B, J. F. (2011). Network Resources and International Performance of High Tech SMEs. Journal of Small Business and Enterprise Development, 18(3), 529-555.

Kuivalainen, O., Puumalainen, K., Sintonen, S., \& Kylaheiko, K. (2010). Organisational Capabilities and Internationalisation of The Small and Medium-Sized Information and Communications Technology firms. International Journal Entrepreneurship, 8, 135-155.

Lan, Q., \& Wu, S. (2010). An Empirical Study of Entrepreneurial Orientation and Degree of Internationalization of Small and Medium Sized Chinese Manufacturing Enterprises. Journal of Chines Entrepreneurship, 2(1), 53-75.

Lee, S. M., \& Lim, S. (2009). Entrepreneurial Orientation and the Performance of Service Business. Journal Service Business, 3, 1-13.

Loncan, T., \& Nique, W. M. (2010). Degree of Internationalization and Performance: Evidence from Emerging Brazilian Multinational Firms. GCG Georgetown University-Universia, 4(1), 40-51.

Lumpkin, G. T., \& Dess, G. G. (1996). Clarifying the Entrepreneurial Orientation Construct and Linking IT to Performance. Academy of Management Review, 21(1), 135-172.

McDougal, O. P, \& Oviatt, B. M. (2003). Some Fundamental Issues in International Entrepreneurship. Entrepreneurship Theory and Practice. 
Melia, M. R., Boulard, M. M., \& Peinado, L. S. (2007). Entreprenurial Orientation and International Commitment. Journal International Entrepreneurship, 5, 65-83.

Ministry of Industry-Strategic Plan: 2010-2014. (2011). Jakarta.

Ministry of Industry- Directorate of SMI. (2009). SMIs Profile in Indonesia. Jakarta

Ministry of Trade-Dit.Jen. (2012). National Export Development. Jakarta

Morales, F. X., \& Fernandez, M. (2010). Social Networks: Effects of Social Capital on Firm Innovation. Journal of Small Business Management, 48(2), 258-279.

Moreno, A., Casillas, M., \& Jose, C. (2008). Entrepreneurial Orientation and Growth of SMEs: A Causal Model. ETP. Baylor University.

Okpara, J. O. (2009b). Strategic Choices, Export Orientation and Export Performance of SMEs in Nigeria. Journal Management Decision, 47(8), 1281-1299.

OECD (Organization for Economic Co-operation and Development). (2009). Top barriers and Drivers to SME Internationalisation. OECD Centre for Entreprenurship, SME and Local Development (CFE). Retrieved from http://www.oecd.org/dataoecd

O'Toole, T., \& Mc Grath, H. (2008). Implementing a Relational Capability Framework through an SME Network. Retrieved from http://www.imgroup.org

Quince, T., \& Whittaker, H. (2003). Entrepreneurial Orientation and Entrepreneurs' Intentions and Objectives. Working Paper. CBR Research Programme on Small and Medium Enterprises.

Rauch, A., Wiklund, J., Lumpkin, G. T., \& Frese, M. (2009). Entreprenurial Orientation and Business Performance: An Assessment of Past Research and Suggestions for the Future. Entreprenurship Theory and Practice, 33(3), 1-54.

Rieck, O., Cheaah, J., Lou, A., \& Lee, S. (2005). The Relationship between Degree of Internationalization and Firm Performance in The Telecomunication Industry. Working paper conference. Nanyang Business School.

Sullivan, D. (1994a). Measuring the Degree of Internationalization of a Firm. Journal of International Business Studies, 325-342.

Sullivan, D. (1994b). The Threshold of Internationalization: "Replication, Extension, and Reinterpretation". Management International Review, 34(2), 165-186.

Suryana, Y., \& Bayu, K. (2010). Kewirausahaan: Pendekatan Karakteristik Wirausahawan Sukses. Jakarta: Kencana Prenada Media Group.

Tambunan, T. (2007). Development of SMEs in a Developing Country: The Indonesian Story. Journal of Business and Entrepreneurship, 19(12), 60-78.

Tambunan, T. (2010a). Development of Small and Medium Enterprises in a Developing Country: The Indonesian Case. Journal of Enterprising Communities People and Places in the Global Economy, 5, 68-82.

Tambunan, T. (2010b). Facilitating SMEs in International Trade (Export): The Case of Indonesia. Asia pacific Trade Economists" Conference Trade-Led Growth in Times Crisis. United Nation-ESCAP.

Tang, Y. K. (2011). The Influence of Networking on the Internationalization of SMEs: Evidence from Internationalized Chinese Firm. International Small Business Journal, 29, 374-398.

Tsai, W., \& Ghoshal, S. (1998). Social Capital and Value Creation: The Role of Intrafirm Networks. Academy of Management Journal, 41(4), 464-476.

Ural, T. (2008). The Effect of Relationship Quality on Export Performance. European Journal of Marketing, $43(1 / 2), 139-168$.

Verdin, P., \& Heck, N. V. (2001). From Local Champions to Global Masters: A strategic Perspectives on Managing Internationalization. New York:Palgrave.

Wellman, B., \& Frank, K. (2000). Network Capital in a Multi-Level World: Getting Support from Personal Communities (pp. 1-17). Social Capital: Theory and Research, Chicago: Aldine De Gruyter.

Wengel, J., \& Rogriguez, E. (2006). SME Export Performance in Indonesia after Crisis. Small Business Economics, 26, 25-37.

Wiklund, J., \& Shepherd, D. (2005). Entrepreneurial Orientation and Small Business Performance: A 
configurational Approach. Journal Business Venturing, 20(1), 71-91.

Winarno. (2011). Pengembangan Sikap Entrepreneurship dan Intrapreneurship. Jakarta: PT Indeks.

Wismiarsi, Tri., Muchsin, S., \& Wijaya, A. (2008). Hambatan Ekspor UKM Nasional: Hasil Studi Pada Industri Mebel, Kerajinan dan Biofarmaka. BSM- Bakrie School of Management. Kompas. Jakarta.

Zain, M., \& Ing, S. (2006). The Impact of Network Relationships on SMEs Internationalization Process. Thunderbird International Business Review, 48(2), 183-205.

Zimmerman, M. A., Barsky, D., \& Brouthers, K. D. (2010). Networks, SMEs, and International Diversification. Multinational Business Review, 17(4), 143-162.

\section{Copyrights}

Copyright for this article is retained by the author(s), with first publication rights granted to the journal.

This is an open-access article distributed under the terms and conditions of the Creative Commons Attribution license (http://creativecommons.org/licenses/by/3.0/). 